DONEL, Pedro Roberto; CATTANI, Marcos José Campos. Futebol ou educação: escolha do Estado ou do Judiciário. Revista Eletrônica Direito e Política, Programa de Pós-Graduação Stricto Sensu em Ciência Jurídica da UNIVALI, Itajaí, v.10, n.2, $1^{0}$ quadrimestre de 2015. Disponível em: www.univali.br/direitoepolitica - ISSN 1980-7791.

\title{
FUTEBOL OU EDUCAÇÃO: ESCOLHA DO ESTADO OU DO JUDICIÁRIO
}

\author{
FOOTBALL OR EDUCATION: CHOICE OF THE STATE OR THE JUDICIARY
}

\author{
Pedro Roberto Donel ${ }^{1}$ \\ Marcos José Campos Cattani
}

SUMÁRIO: Introdução; 1. Do Estado liberal ao Estado Democrático De Direito e a expansão do Poder Judiciário no mundo e no Brasil; 2. A judicialização da política e o ativismo judicial. Uma breve introdução; 3 . O Ativismo Judicial; 4. Judicialização da política. A decisão do juiz Alexandre Morais Da Rosa, a posição do Tribunal de Justiça de Santa Catarina e do STJ; Considerações Finais; Referências das Fontes Citadas.

RESUMO: A partir da citação por Lenio Streck ${ }^{3}$ de uma decisão do juiz de direito Alexandre Morais da Rosa ${ }^{4}$, na Comarca de Joinville, atendendo ação civil pública promovida pelo Ministério Público, determinando à municipalidade a criação de quase 3000 vagas na rede pública de ensino com o dinheiro que havia "preferido" investir na construção do estádio do JEC - Joinville Esporte Clube, cria-se uma análise para revisar o fenômeno do protagonismo judicial e a distinção entre ativismo judicial e judicialização da política, além de sua recepção pelo Tribunal de Justiça de Santa Catarina, Superior Tribunal de Justiça e Supremo Tribunal Federal.

\footnotetext{
${ }^{1}$ Bacharel em Direito, Especialista em Direito Processual Civil pela Universidade Federal do Paraná, Pós-Graduado Lato Sensu em Direito Previdenciário Pela Faculdade Arthur Thomas, Mestrando em Ciência Jurídica pela Universidade do Vale do Itajaí - UNIVALI - SC. Advogado e Conselheiro Estadual da OAB/SC - 2013/2015, inscrito no no 11.888.

2 Bacharel em Direito e Mestrando em Ciência Jurídica pela Universidade do Vale do Itajaí UNIVALI - SC. Advogado e Conselheiro Estadual da OAB/SC - 2013/2015, inscrito no no 14.773. Foi membro do 10 Tribunal de Ética e Disciplina, de 2008/2012.

3 STRECK, Lenio Luiz. Hermenêutica Jurídica e(m) Crise: uma exploração hermenêutica da construção do Direito. 10. Ed. Porto Alegre: Livraria do Advogado 2011. p. 65.

${ }^{4}$ Nos autos do Proc. 038.03.008229-0.
} 
DONEL, Pedro Roberto; CATTANI, Marcos José Campos. Futebol ou educação: escolha do Estado ou do Judiciário. Revista Eletrônica Direito e Política, Programa de Pós-Graduação Stricto Sensu em Ciência Jurídica da UNIVALI, Itajaí, v.10, n.2, $1^{\circ}$ quadrimestre de 2015. Disponível em: www.univali.br/direitoepolitica - ISSN 1980-7791.

Palavras-chave: Protagonismo judicial; Judicialização da política; Constitucionalismo; Neoconstitucionalismo; Constitucionalismo Contemporâneo; Judiciário; Ativismo.

ABSTRACT: After a quote by Lenio Streck about a decision from court judge Alexandre Morais da Rosa, in the county of Joinville, attending civil action promoted by the prosecutors, demanding to the township the creation of almost 3000 vacancies in public school system with the money he preferred to use in the construction of the Joinville Sport Club stadium, a review is created in order to analyze the role of the judicial phenomenon and the distinction between judicial activism and legalization of politics, and its receipt by the Court of Santa Catarina, Superior Court and Supreme Court as well.

Keywords: Judicial role. Legalization of politics. Constitutionalism. Neoconstitutionalism. Contemporary constitutionalism. Judiciary. Activism.

\section{INTRODUÇÃO}

O caso referido por Lenio Streck chamou a atenção. Na época em que a liminar foi deferida (2003) - posteriormente cassada pelo Tribunal de Justiça de Santa Catarina - para determinar que o dinheiro que se pretendia investido no Estádio do JEC - Joinville Esporte Clube fosse aplicado na educação, o time estava na terceira divisão e jogava num campo com arquibancadas de madeira e ferro, o famoso, e hoje saudoso, "Ernestão".

Hoje o clube joga na Arena Joinville, que acabou sendo construída pelo Município ${ }^{5}$, e está na primeira divisão. De um time sem série, já que houve uma época em que o JEC não jogava nem na série $D$, hoje é um dos melhores de Santa Catarina e do Brasil.

O processo tramitou em segredo de justiça por se tratar de feito afeto a Vara de Infância e Juventude, mas a sentença está disponível na integra na internet ${ }^{6}$,

\footnotetext{
${ }^{5}$ A liminar foi cassada e o Estádio construído, inclusive, foi palco de uma briga entre torcidas no jogo entre Atlético Paraná X Vasco, no dia 8 de dezembro de 2013, com repercussão nacional. Notícia aqui: http://globoesporte.globo.com/futebol/brasileirao-serie-a/noticia/2013/12/briga-naarquibancada-paralisa-jogo-entre-furacao-e-vasco.html (acessado no dia 14 de janeiro de 2015).

${ }^{6}$ Sentença disponível em: http://www.cis.puc-rio.br/cedes/PDF/06marco/liminar.pdf.
} 
DONEL, Pedro Roberto; CATTANI, Marcos José Campos. Futebol ou educação: escolha do Estado ou do Judiciário. Revista Eletrônica Direito e Política, Programa de Pós-Graduação Stricto Sensu em Ciência Jurídica da UNIVALI, Itajaí, v.10, n.2, 10 quadrimestre de 2015. Disponível em: www.univali.br/direitoepolitica - ISSN 1980-7791.

para livre acesso. O agravo de instrumento que cassou a liminar recebeu o número 2003.010276-0, no Tribunal de Justiça de Santa Catarina.

A decisão judicial referida que determinou a criação de quase três mil vagas na rede de ensino é um caso clássico de judicialização da política, que será mais bem explicada adiante, e que difere de ativismo judicial.

São direitos sociais de todo cidadão brasileiro, previsto no artigo $6^{\circ}$ da Constituição Federal, entre outros, a educação e o lazer, mas evidente que por conveniência política não se pode desviar dinheiro da educação para investir num clube de futebol, mesmo que seja com a nobre missão de levar o time a primeira divisão para deleite dos amantes de futebol e que interessa a comunidade joinvilense (e o futebol, nesse ponto, é um catalisador na busca pela simpatia popular). É evidente que não se pode investir no lazer a custa do aumento do analfabetismo.

A confusão entre público e privado, do uso do Estado para fins eleitorais, de empresas públicas e de economia mista, para benefício de partidos e particulares são hoje os maiores problemas para a democracia brasileira. "Mensalão", "Petrolão", e outros casos estão arrastando para o ralo da corrupção bilhões, senão trilhão de reais, que poderiam ser investidos em educação, saúde e segurança. Os mecanismos de controle da administração pública, as agências reguladoras, estão todas aparelhadas, nada investigam. As Comissões Parlamentares de Inquéritos são dominadas pelos políticos da situação e produzem relatórios pífios, senão risíveis, afirmando que tudo está em ordem, que a corrupção só existe na cabeça da oposição, e o Brasil vai muito bem, obrigado.

Apesar de o nosso país ser governado há exatos 12 anos pelo Partido dos Trabalhadores, a desigualdade só aumenta. O Poder mudou de mãos, saindo da elite do PSDB que governou o país por 8 anos, sendo para muitos um governo "neoliberal"7, e entrou um partido mais voltado ao social, um partido que não era

\footnotetext{
7 Extensa liberalização econômica, livre comércio e a redução da despesa pública como forma de reforçar o papel do setor privado na economia.
} 
DONEL, Pedro Roberto; CATTANI, Marcos José Campos. Futebol ou educação: escolha do Estado ou do Judiciário. Revista Eletrônica Direito e Política, Programa de Pós-Graduação Stricto Sensu em Ciência Jurídica da UNIVALI, Itajaí, v.10, n.2, 10 quadrimestre de 2015. Disponível em: www.univali.br/direitoepolitica - ISSN 1980-7791.

formado por patrões e sim por trabalhadores e, entretanto, a miséria aumentou e a dilapidação da coisa pública atingiu o seu ápice, fato que é público e notório. Raymundo Faoro explica que o problema está na origem portuguesa, fazendo com que o poder político se articule a partir de um estado que é patrimonialista em seu conteúdo e estamental na forma.

Patrimonialista porque os detentores do poder privatizam em seu benefício 0 Estado e as empresas estatais, misturando o público e o privado, objetivando o enriquecimento ilícito próprio. O Estamento dá forma a esse exercício de poder.

Os atuais detentores do poder não se importam com a incompetência evidente de seus amigos instalados nos ministérios e cargos de chefia das maiores empresas estatais do Brasil e nas agências reguladoras, insistindo na manutenção dos cargos até que a Polícia Federal os prenda na aurora do dia.

A nova Casta, que governa o Brasil desde 2002, se acha acima da lei, desconhecendo as características fundamentais do Estado moderno e o ambiente que viceja, ou deveria vicejar, no Estado Democrático de Direito, em que os direitos da sociedade são garantidos pela Constituição da forma mais ampla possível.

Tem-se a impressão que a finalidade do Estado brasileiro é criar uma nova casta, enriquecer os membros dos partidos da situação, esquecendo-se dos direitos sociais e fundamentais previstos na Constituição.

Cabe ao Judiciário assumir sua função constitucional e zelar pela democracia, considerando que o Executivo e Legislativo estão enfraquecidos. Faltam-lhes agentes virtuosos. É que se tem observado na Justiça Federal, na Justiça Estadual, no STJ e STF, com um protagonismo que está fazendo bem ao Brasil, desde que dentro dos limites traçados pela Constituição e observando o princípio da legalidade.

A decisão do juiz Alexandre Moraes da Rosa, prolatada em 2003, levou a uma pesquisa no Tribunal de Justiça Catarinense, no Superior Tribunal de Justiça e no Supremo Tribunal Federal, e a constatação de que o ativismo judicial está sendo 
DONEL, Pedro Roberto; CATTANI, Marcos José Campos. Futebol ou educação: escolha do Estado ou do Judiciário. Revista Eletrônica Direito e Política, Programa de Pós-Graduação Stricto Sensu em Ciência Jurídica da UNIVALI, Itajaí, v.10, n.2, $1^{\circ}$ quadrimestre de 2015. Disponível em: www.univali.br/direitoepolitica - ISSN 1980-7791.

rejeitado, mas que a judicialização da política está sendo efetivada, com exceção do STF em que há um ativismo proposital no sentido de substituir o legislativo na edição e alteração de leis e até da Constituição.

Ao que parece essa postura ativista é uma tendência consolidada do nosso Supremo, amparada na máxima de que se no Estado Liberal o protagonismo foi do Legislativo e no Estado Social do Executivo, agora, na vigência do Estado Democrático de Direito, é a vez do Judiciário.

No entanto, esta tendência não pode desaguar em posturas ativistas que representem riscos democráticos. Para isso necessário que o protagonismo seja do Direito.

\section{DO ESTADO Liberal AO ESTADO DEMOCRÁtico de DiReito e A EXPANSÃO DO PODER JUDICIÁRIO NO MUNDO E NO BRASIL}

Hodiernamente experimentamos no Brasil, com atraso em relação ao resto do mundo ocidental, o Estado Democrático de Direito, passando as decisões, em certa medida, do Legislativo (no Estado Liberal) e Executivo (no Estado Social) para o Judiciário.

O atual estágio de desenvolvimento do Estado, nominado por Lenio Streck, de Constitucionalismo Contemporâneo ${ }^{8}$ em crítica ao(s) neoconstitucionalismo(s) ${ }^{9}$ (especialmente surgidos no seio do constitucionalismo espanhol), é fruto de uma evolução histórica muito bem explicada por Paulo Bonavides em sua obra ${ }^{10}$ "DO

\footnotetext{
${ }^{8}$ Afirma o jurista: "Assim, para efeitos dessas reflexões e a partir de agora, passarei a nominar Constitucionalismo Contemporâneo (com iniciais maiúsculas) o movimento que desaguou nas Constituições do segundo pós-guerra e que ainda está presente em nosso contexto atual, para evitar os mal entendidos que permeiam o termo neoconstitucionalismo". STRECK, Lenio Luiz, Verdade consenso: constituição, hermenêutica e teorias discursivas. 4. Ed. São Paulo: Saraiva, 2011, p. 37.

${ }^{9}$ Segundo Luís Roberto Barroso, ministro do Supremo Tribunal Federal, o neoconstitucionalismo identifica um conjunto amplo de transformações ocorridas no Estado e no direito constitucional, como a formação do Estado constitucional de direito, cuja consolidação se deu ao longo das décadas finais do século $X X$. Desse conjunto de fenômenos resultou um processo extenso e profundo de constitucionalização do Direito.

${ }^{10}$ BONAVIDES, Paulo. Do Estado Liberal ao Estado Social. 8. ed. São Paulo: Malheiros Editores, 2004.
} 
DONEL, Pedro Roberto; CATTANI, Marcos José Campos. Futebol ou educação: escolha do Estado ou do Judiciário. Revista Eletrônica Direito e Política, Programa de Pós-Graduação Stricto Sensu em Ciência Jurídica da UNIVALI, Itajaí, v.10, n.2, $1^{0}$ quadrimestre de 2015. Disponível em: www.univali.br/direitoepolitica - ISSN 1980-7791.

ESTADO LIBERAL AO ESTADO SOCIAL". No Estado Liberal o protagonismo foi do Poder Legislativo e no Estado Social, do Executivo.

Em seu livro Hermenêutica Jurídica e(m) Crise Lenio Streck ${ }^{11}$ afirma:

Por tudo isso, é possível sustentar que, no Estado Democrático de Direito, ocorre certo deslocamento do centro de decisões do Legislativo e do Executivo para o plano da justiça constitucional. Pode-se dizer, nesse sentido, que no Estado Liberal, o centro de decisão apontava para o Legislativo (o que não é proibido é permitido, direitos negativos); no Estado Social, a primazia ficava com o Executivo, em face da necessidade de realizar políticas públicas e sustentar a intervenção do Estado na economia, já no Estado Democrático de Direito, o foco de tensão se volta para o Judiciário.

Dito de outro modo, se com o advento do Estado Social e o papel fortemente intervencionista do Estado, o foco de poder/tensão passou para o Poder Executivo, no Estado Democrático de Direito há uma modificação desse perfil. Inércias do Executivo e falta de atuação do Legislativo passam a poder - em determinadas circunstâncias - ser supridas pelo Judiciário, justamente mediante a utilização dos mecanismos jurídicos previstos na Constituição que estabeleceu o Estado Democrático de Direito.

Vê-se que numa evolução histórcia os três poderes alternaram seu protagonismo, não de forma consciente, mas pela evolução dos direitos individuais e sociais, chamados fundamentais.

O Estado Democrático de Direito estreou no Brasil com atraso, por conta dos regimes ditatoriais que vigoraram até 1985, quando houve a eleição indireta para presidente da República e iniciou-se o processo constituinte em 1987-88. A praga dos golpes ditatoriais que no nosso País ocorreu em 1964, espalhou-se por toda a América Latina (Colômbia, em 1953; Argentina, em 1966; e Chile e Uruguai, em 1973). Aliás, a tendência da América Latina ao atraso é visceral, pois apesar dos meios acadêmicos pregarem a era do Estado Democrático de Direito, os donos do Poder insistem em praticar o Estado Social, defendido por

\footnotetext{
${ }^{11}$ BONAVIDES, Paulo. Do Estado Liberal ao Estado Social. 8. ed. São Paulo: Malheiros Editores,
} 2004, p. 63. 
DONEL, Pedro Roberto; CATTANI, Marcos José Campos. Futebol ou educação: escolha do Estado ou do Judiciário. Revista Eletrônica Direito e Política, Programa de Pós-Graduação Stricto Sensu em Ciência Jurídica da UNIVALI, Itajaí, v.10, n.2, 10 quadrimestre de 2015. Disponível em: www.univali.br/direitoepolitica - ISSN 1980-7791.

Paulo Bonavides, na década de 50, sem se atentar para os comandos constitucionais.

A propósito Lenio Streck ${ }^{12}$ esclarece:

Estamos, assim, em face de um sério problema: de um lado temos uma sociedade carente de realização de direitos e, de outro, uma Constituição Federal que garante estes direitos de forma mais ampla possível. Este é o contraponto. Daí a necessária indagação: qual é o papel do Direito e da dogmática jurídica neste contexto? Segundo Morais, o Estado Democrático de Direito, teria (tem?) a característica de ultrapassar não só a formulação do Estado Liberal de Direito, com também a do Estado Social de Direito vinculado ao Welfare state neocapitalista - impondo à ordem jurídica e à atividade estatal um conteúdo utópico de transformação da realidade. O Estado Democrático de Direito, ao lado do núcleo liberal agregado á questão social, tem como questão fundamental a incorporação efetiva da questão da igualdade como um conteúdo próprio a ser buscado garantir através do asseguramento mínimo de condições mínimas de vida ao cidadão e à comunidade. Ou seja, no Estado Democrático de Direito a lei passa a ser, privilegiadamente, um instrumento de ação concreta do Estado, tendo como método assecuratório de sua efetividade a promoção de determinadas ações pretendidas pela ordem jurídica. Entretanto, isso não foi ainda suficientemente assimilado pelos juristas.

No resto do mundo o protagonismo do Poder Judiciário passou a ser discutido de forma mais intensa no período posterior à segunda guerra mundial, com o objetivo de superar as atrocidades cometidas, principalmente, pelo regime nazista, ${ }^{13}$ que eram legitimados por uma estrutura legislativa, produzida observando-se o procedimento adequado para a criação das leis, e obedecida de forma cega pela sociedade.

O pós-guerra proporcionou uma readequação institucional com o objetivo de garantir direitos fundamentais constitucionalmente assegurados, configurando-

12 STRECK, Lenio Luiz. Hermenêutica Jurídica e(m) Crise: uma exploração hermenêutica da construção do Direito. 10. ed. Livraria do Advogado, 2011. Pg. 47.

13 Predominava a corrente filosófica da subsunção positivista, conforme LARENZ, Karl. Medologia de La ciência del derecho. Tradução de Marcelino Rodriguez Molinero. Barcelona: Ariel S.A., 1994 , p. 141. 
DONEL, Pedro Roberto; CATTANI, Marcos José Campos. Futebol ou educação: escolha do Estado ou do Judiciário. Revista Eletrônica Direito e Política, Programa de Pós-Graduação Stricto Sensu em Ciência Jurídica da UNIVALI, Itajaí, v.10, n.2, $1^{\circ}$ quadrimestre de 2015. Disponível em: www.univali.br/direitoepolitica - ISSN 1980-7791.

se, assim, a transição do que se conhecia por Estado Legislativo de Direito para um Estado Constitucional de Direito. ${ }^{14}$

Sob essa perspectiva e utilizando o ensinamento doutrinário de Hans Kelsen ${ }^{15}$, o Executivo e o Legislativo ensejaram a criação de Tribunais Constitucionais, incorporando a noção de constitucionalismo democrático, passando a aplicação do direito a considerar, além da legislação, a jurisprudência de valores, ${ }^{16}$ que dispensa até mesmo o texto constitucional.

Após o período negro da Ditadura, em que o Direito ficou reduzido a lei, ${ }^{17}$ ou mais precisamente a partir da promulgação da Constituição Cidadã em 1988, o constitucionalismo brasileiro passou a importar os avanços experimentados pelo continente europeu após a segunda guerra mundial, quando estreou em nossa terra a proposta teórica de José Joaquim Gomes Canotilho do "constitucionalismo dirigente", na qual afirma "a força atuante do direito constitucional". ${ }^{18}$ Paulatinamente os códigos perdem forças e a Constituição passa a reinar com maior protagonismo.

Como no Brasil aparece o elemento jurisdicional do Estado que, na relação entre os Poderes, dão ênfase ao Judiciário, a partir da Constituição de 1988, o Constitucionalismo Contemporâneo ou neoconstitucionalismo é identificado por um protagonismo da atividade jurisdicional por parcela considerável de juristas e até mesmo pelos membros que compõem o Judiciário, e aqui começa a nascer a necessidade de distinguir o que é ativismo judicial e judicialização da política

14 FERRAJOLI, Luigi. Sobre los derechos fundamentales. Tradução de Miguel Carbonell. In: CARBONELL, Miguel (Org.). Teoría del neoconstitucionalismo: ensayos escogidos. Madrid: Trota, 2007, p. 72-3.

15 De acordo com o modelo desenvolvido por Kelsen, que visava a criação de um órgão competente autônomo, o tribunal constitucional atuaria como um "legislador negativo", pois não teria a faculdade de criar leis, mas revogá-las, total ou parcialmente, caso houvesse conflitos com o que estivesse disposto na Constituição.

16 LAMEGO, José. Hermenêutica e jurisprudência: análise de uma "recepção". Lisboa: Fragmentos, 1990, p. 60.

17 LOPEZ MEDINA, Diego Eduardo. Teoria Impura del direcho: La transformacion de la cultura jurídica latinoamericana. Bogotá: Lagis, 2004.

18 CANOTILHO, José Joaquim Gomes. Constituição dirigente e vinculação do legislador: contributo para a compreensão das normas constitucionais programáticas. 2 ed. Coimbra: Coimbra Editora, 2001, p. 27. 
DONEL, Pedro Roberto; CATTANI, Marcos José Campos. Futebol ou educação: escolha do Estado ou do Judiciário. Revista Eletrônica Direito e Política, Programa de Pós-Graduação Stricto Sensu em Ciência Jurídica da UNIVALI, Itajaí, v.10, n.2, $1^{\circ}$ quadrimestre de 2015. Disponível em: www.univali.br/direitoepolitica - ISSN 1980-7791.

para uma melhor compreensão do fenômeno e sua correta aplicação, o que será tratado no tópico seguinte.

\section{A JUDICIALIZAÇÃo DA POLÍtICA E O ATIVISMO JUDICIAL. UMA BREVE INTRODUÇÃO}

Qual o papel dos juízes e Tribunais num Estado Democrático de Direito?

Aqui interessa analisar o procedimentalismo ${ }^{19}$ e substancialismo ${ }^{20}$, ou seja, qual o tipo de atividade que a jurisdição realiza a interpretar a constituição. Para aqueles que adotam a corrente procedimentalista cabe ao intérprete verificar apenas o aspecto formal do jogo democrático. Já os substancialistas veem o Judiciário como ente responsável para garantir e fortalecer as instituições democráticas.

Lenio Streck ${ }^{21}$ esclarece que a adoção da postura substancialista não autoriza o ativismo judicial para concretizar direito. O juiz precisa ficar adstrito ao que está na Constituição, principalmente no que diz respeito a igualdade, justiça social e a garantia dos direitos humanos fundamentais, não podendo valer-se de critérios pessoais, políticos e morais.

Defendem a corrente procedimentalista Habernas, Garapon e Ely e a substancialista Capepelletti e Dworkin, Paulo Bonavides, Celso Antônio Bandeira de Melo, entre outros.

\footnotetext{
19 Os procedimentalistas acentuam o papel instrumental da Constituição: ela estaria primordialmente voltada à garantia de instrumentos de participação democrática e à regulação do "processo" de tomada de decisões, com a consequente valorização da liberdade política inerente à concepção democrática. Cf. ELY, John Hart. Democracy and Distritus: a Theory of judicial review, $11^{\text {a }}$ edição, Cambridge, Harvard University, 1995, p. 88.

20 Os substancialistas valorizam o conteúdo material das Constituições, atribuindo-Ihes um papel diretivo, cabendo à lei operacionalizar a concretização dos vetores axiológicos que contemplam (por exemplo: os direitos sociais). Cf. TRIBE, Constitutional Choices. Cambridge: Harvard University Press, 1985, p. 3/28.

${ }^{21}$ STRECK, Lenio Luiz. Hermenêutica Jurídica e(m) Crise: uma exploração hermenêutica da construção do Direito. 10. Ed. Porto Alegre: Livraria do Advogado 2011, p. 52.
} 
DONEL, Pedro Roberto; CATTANI, Marcos José Campos. Futebol ou educação: escolha do Estado ou do Judiciário. Revista Eletrônica Direito e Política, Programa de Pós-Graduação Stricto Sensu em Ciência Jurídica da UNIVALI, Itajaí, v.10, n.2, 10 quadrimestre de 2015. Disponível em: www.univali.br/direitoepolitica - ISSN 1980-7791.

Fica, portanto, bem claro que quem defende a corrente substancialista não está defendendo o ativismo judicial.

O crescimento da atuação jurisdicional é amplamente debatido nos Estados Unidos desde a instituição do controle de constitucionalidade (judicial review) em 1803, com grande acervo de obras tratando das atribuições, limites e competência do Poder Judiciário, todas datadas de antes da década de $90 .{ }^{22}$

Na Europa, como visto no capítulo anterior, o protagonismo do Poder Judiciário começou com o movimento democrático surgido a partir do segundo pós-guerra em resposta aos regimes autoritários/ditatoriais, cujas constituições positivam os direitos fundamentais e sociais e redimensionam a relação entre os Poderes do Estado. ${ }^{23}$

Dito isto, estamos prontos para diferenciar judicialização da política e ativismo judicial.

\section{O ATIVISMO JUDICIAL}

O ativismo judicial vem sendo debatido há mais de duzentos anos nos Estados Unidos desde 1803, com o caso Marbury versus Madison, que originou o controle de constitucionalidade norte-americano (judicial review).

Apesar de o constitucionalismo americano prezar pela separação dos poderes, na sua forma clássica, a Suprema Corte desde 1803 exerce um papel imponente, pois a Constituição apesar de ser um documento definitivo que preza pela proteção de liberdades tem conteúdo mínimo e vago, com direitos enumerados e

\footnotetext{
22 Por exemplo, as obras de John Hart Ely (Democracy and distrust, 1980), de Charles Beard (The Supreme Court and the Constitutiom, 1912, na versão sem a introdução de Alan Westin, edição que foi publicada em 1962), de Alexandre Bickel (The Last Dangerous Branch: the Supreme Court at the Bar of Politics, 1962), de Raoul Berger (Government by Judiciary, 1977) e de Laurence Tribe (Constitucion Choices, 1986).

23 VIANA, Luiz Weneck; CARVALHO, Maria Alice Rezende de; CUNHA MELO, Manuel Palácios; BURGOS, Marcelo Baumann. A judicialização da política e das relações sociais no Brasil. Rio de Janeiro: Editora Ravan, p. 22 e 23.
} 
DONEL, Pedro Roberto; CATTANI, Marcos José Campos. Futebol ou educação: escolha do Estado ou do Judiciário. Revista Eletrônica Direito e Política, Programa de Pós-Graduação Stricto Sensu em Ciência Jurídica da UNIVALI, Itajaí, v.10, n.2, $1^{0}$ quadrimestre de 2015. Disponível em: www.univali.br/direitoepolitica - ISSN 1980-7791.

não enumerados, permitindo uma atuação ativista da Suprema Corte pelo judicial review e definindo questões controversas. ${ }^{24}$

Aqui entra o nosso conhecido Ronald Dworkin ${ }^{25}$ com a "leitura moral da Constituição", no qual teoriza que os direitos individuais são princípios morais e limitam o poder governamental, permitindo a ampliação dos direitos constitucionais previstos:

[...] o governo deve tratar todos os sujeitos sob seu domínio como possuidores de igual status moral e político; ele deve tentar, com boa fé, tratar a todos com igual respeito; e deve respeitar quaisquer que sejam as liberdades individuais que sejam indispensáveis para estes fins, incluindo, mas não se limitando às liberdades mais especificadamente designadas do documento, como liberdade de expressão e religião.

A moral como elemento de ampliação dos direitos fundamentais gerou desconfiança sobre as Cortes, considerando que os juízes poderiam impor suas próprias convicções morais ao decidir. Efetivamente é o que acontece na prática e a Suprema corte tem era "liberal" ou "conservadora", que, ao final, representa a vontade popular, considerando que os juízes são indicados pelo Presidente, eleito democraticamente.

A leitura moral da constituição, entretanto, não representa ativismo judicial.

A teoria de Dworkin, bem como de outros autores americanos (Richard A. Posner e Oliver Wendel Holmes apenas para citar dois), não pode ser importada para o Brasil, considerando que nosso texto constitucional é pródigo na enumeração dos direitos e garantias e estabelece objetivo de bem-estar ao Estado. A moral particular e individual do juiz não pode servir como fundamentação de uma decisão judicial, o que caracteriza o ativismo judicial.

\footnotetext{
${ }^{24}$ TRACHTMAN, Michael G. The Supreme's greatest hits: the 37 Supreme Court Cases that most directly affesct your life. New York/London Sterling, 2009. p. 1 e 2.

${ }^{25}$ DWORKIN, Ronald. Freedam's Law: the moral reading of the american constitution. Oxford: Oxford University Press, 2005, p. 7. Tradução livre. No original:[...] govennent must treat all those subject to its domiion as having equal moral and political status; it must attempt, in good faith, to treat them all with equal concern; and It must respect whatever individual freedoms are indispensable to those ends, including but not limited to the freedoms more specifically designated in the document, such as the freedoms of speech and religion".
} 
DONEL, Pedro Roberto; CATTANI, Marcos José Campos. Futebol ou educação: escolha do Estado ou do Judiciário. Revista Eletrônica Direito e Política, Programa de Pós-Graduação Stricto Sensu em Ciência Jurídica da UNIVALI, Itajaí, v.10, n.2, 10 quadrimestre de 2015. Disponível em: www.univali.br/direitoepolitica - ISSN 1980-7791.

Além da teoria do direito não numerado, Laurence $H$. Tribe ${ }^{26}$ faz referência a "Constituição Invisível", com o intuito de demonstrar que a enxuta Constituição Americana com sete artigos e vinte e sete emendas silencia em várias questões. Diferente da nossa, lá a constitucionalidade precisa ser entendida para além de sua textualidade. O Judiciário, numa perspectiva histórica, filosófica, moral e política, com um pé nas teorias de linguagem, na questão institucional, precisa ver na Constituição o que não está escrito, o que ensejaria o ativismo judicial.

Já Christopher Wolfe ${ }^{27}$ afirma que os juízes e tribunais assumem posturas legislativas, no que ele chama de Poder Judiciário Moderno. Para identificar o ativismo, Wolfe diz que é preciso observar se a decisão foi tomada considerando a vontade da Constituição ou a vontade política e crença do juiz.

Ronald Dworkin ${ }^{28}$ constrói sua teoria para combater o positivismo e o pragmatismo. Diz que o direito é um conjunto de práticas sociais que devem ser interpretadas. Na sua teoria busca a intenção e a finalidade do direito. A intencionalidade concebida como um corpo coerente, integrado e articulado, na busca de uma prática social compartilhada, com a finalidade de obter a melhor interpretação, na melhor resposta. Afirma que o intérprete tem que perseguir, através da construção e reconstrução de conceitos, com debates, a interpretação que melhor se coaduna com a finalidade do Direito, o que significa a afirmação de uma teoria substantiva da política e da justiça. Vê-se que a teoria de Dworkin faz referência a teoria moral, teoria política, teoria da igualdade e finalmente a teoria da democracia, nas quais os juízes e demais operadores de direito têm responsabilidades, o que é relevante na defesa do ativismo judicial.

O problema é que o Brasil importou todas estas teorias do ativismo judicial, referidas acima numa apertada síntese, sem levar em consideração as especificidades do solo brasileiro.

\footnotetext{
${ }^{26}$ TRIBE, Laurence. The invisible constitution. Oxford University Press, 2008. p. xiv.

${ }^{27}$ WOLFE, Christopher. Judicial activism: bulwark of freedom or precarious security? New York: Rowman \& Littlefield Publisher, Inc., 1997, p. 1.

${ }^{28}$ DWORKIN, Ronald. Law as Interpretatition. In; - A matter of principle. New York: Oxford University Press, 2001, p. 119-180.
} 
DONEL, Pedro Roberto; CATTANI, Marcos José Campos. Futebol ou educação: escolha do Estado ou do Judiciário. Revista Eletrônica Direito e Política, Programa de Pós-Graduação Stricto Sensu em Ciência Jurídica da UNIVALI, Itajaí, v.10, n.2, $1^{0}$ quadrimestre de 2015. Disponível em: www.univali.br/direitoepolitica - ISSN 1980-7791.

Aqui impossível não fazer referência a obra de Lenio Streck ${ }^{29}$ que estabelece premissas para fazer prevalecer o Constitucionalismo Contemporâneo e vencer o ativismo judicial. Refere que é preciso enfrentar a importação equivocada das teorias desenvolvidas nos Estados Unidos da América durante séculos, superar a discricionariedade judicial e preservar a autonomia do Direito.

Refere que é preciso negar as teorias alienígenas, principalmente a ponderação alexyana $^{30}$, que não é compatível com a realidade brasileira.

A propósito da ponderação de valores Lenio Streck, como visto na nota de rodapé, diz que ela é pouco compreendida em solo brasileiro, inclusive pelo STF, e pediu, em artigo publicado no Conjur em 8 de janeiro de $2014^{31}$, que a presidente Dilma vetasse o $\S 20$, do artigo 489 do Código de Processo Civil de $2015^{32}$, mantendo-se na íntegra a cabeça do artigo e seu parágrafo $1^{\circ}$, pois ele está de acordo com o artigo 93, inciso IX da CF.

\footnotetext{
${ }^{29}$ STRECK, Lenio Luiz. Hermenêutica jurídica e(m) crise.

30 A propósito sobre a tese 'ponderação de valores' e 'colisão entre normas' (sic), o autor faz severa crítica ao parágrafo $2^{\circ}$ do artigo 487 do NCPC, vazado nos seguintes termos: "§ 2 . No caso de colisão entre normas, o juiz deve justificar o objeto e os critérios gerais da ponderação efetuada, enunciando as razões que autorizam a interferência na norma afastada e as premissas fáticas que fundamentam a conclusão". Diz que a teoria criada pelo alemão Alexy nunca foi muito bem entendida e aplicada por aqui, nem pelo STF, segundo trabalhado de doutorado conduzido por Fausto de Moraes, diante de sua complexidade, e explica: "A complexidade da 'tese da ponderação'". Alexy não diz que a ponderação que o Tribunal Alemão faz seria irracional, mas que ela seria passível de racionalidade pela teoria que ele propôs. Assim, pode-se dizer que Alexy é um defensor da possibilidade de fundamentação racional argumentativa das decisões que ponderam (embora ele não critique as decisões do Tribunal).
}

31 Acessado hoje: http://www.conjur.com.br/2015-jan-09/lenio-streck-nem-todos-gatos-saopardos-cpc

32 O artigo não foi vetado, e sua redação ficou assim: Art. 489. São elementos essenciais da sentença:

I - o relatório, que conterá os nomes das partes, a identificação do caso, com a suma do pedido e da contestação, e o registro das principais ocorrências havidas no andamento do processo;

II - os fundamentos, em que o juiz analisará as questões de fato e de direito;

III - o dispositivo, em que o juiz resolverá as questões principais que as partes lhe submeterem.

$\S 1^{\circ}$ Não se considera fundamentada qualquer decisão judicial, seja ela interlocutória, sentença ou acórdão, que:

I - se limitar à indicação, à reprodução ou à paráfrase de ato normativo, sem explicar sua relação com a causa ou a questão decidida;

II - empregar conceitos jurídicos indeterminados, sem explicar o motivo concreto de sua incidência no caso; 
DONEL, Pedro Roberto; CATTANI, Marcos José Campos. Futebol ou educação: escolha do Estado ou do Judiciário. Revista Eletrônica Direito e Política, Programa de Pós-Graduação Stricto Sensu em Ciência Jurídica da UNIVALI, Itajaí, v.10, n.2, $1^{0}$ quadrimestre de 2015. Disponível em: www.univali.br/direitoepolitica - ISSN 1980-7791.

Esclarece, Lenio Streck, que tal dispositivo permite um maior controle das decisões judiciais, evita a discricionariedade judicial e é o "corolário da democracia".

Ensina Alexy ${ }^{33}$ :

Princípios contém, pelo contrário [das regras], um dever ideal. Eles são mandamentos a serem otimizados [...]. A forma de aplicação para eles típicas é, por isso, a ponderação. Somente a ponderação leva o do dever-primafacie ideal ao dever real e definitivo.

Vê-se que Alexy, como também ensina Lenio Streck, fala de confronto entre princípio e nossos legisladores falam de "colisão entre normas", suficiente para abrir as portas para o ativismo judicial.

A polêmica surgida após o artigo de Lenio Streck para que a presidente Dilma vetasse o referido dispositivo recebeu a adesão de André Karam e Fausto Santos de Morais $^{34}$, que no dia 10 de janeiro de 2015, publicaram artigo com o título "Debate sobre ponderação no Novo CPC e os perigos do decisionismo", fazendo coro a crítica de Lenio Streck.

Esclarecem referidos articulistas que a teoria de Robert Alexy é associada a ideia de "proporcionalidade" e quando se verifica uma "colisão de princípios". Deve ser aplicada pelo juiz quando na "resolução do caso concreto" levando em

III - invocar motivos que se prestariam a justificar qualquer outra decisão;

IV - não enfrentar todos os argumentos deduzidos no processo capazes de, em tese, infirmar a conclusão adotada pelo julgador;

V - se limitar a invocar precedente ou enunciado de súmula, sem identificar seus fundamentos determinantes nem demonstrar que o caso sob julgamento se ajusta àqueles fundamentos;

VI - deixar de seguir enunciado de súmula, jurisprudência ou precedente invocado pela parte, sem demonstrar a existência de distinção no caso em julgamento ou a superação do entendimento.

$\S 2^{\circ}$ No caso de colisão entre normas, o juiz deve justificar o objeto e os critérios gerais da ponderação efetuada, enunciando as razões que autorizam a interferência na norma afastada e as premissas fáticas que fundamentam a conclusão.

$\S 3^{\circ}$ A decisão judicial deve ser interpretada a partir da conjugação de todos os seus elementos e em conformidade com o princípio da boa-fé.

33 ALEXY, Robert. Constitucionalismo discursivo. Tradução de Luís Afonso Heck. 2. Ed. Porto Alegre: Livraria do Advogado, 2008, p. 37.

34 Acessado em 14 de janeiro de 2015: http://www.conjur.com.br/2015-jan-10/diario-classedebate-ponderacao-cpc-perigos-decisionismo 
DONEL, Pedro Roberto; CATTANI, Marcos José Campos. Futebol ou educação: escolha do Estado ou do Judiciário. Revista Eletrônica Direito e Política, Programa de Pós-Graduação Stricto Sensu em Ciência Jurídica da UNIVALI, Itajaí, v.10, n.2, $1^{\circ}$ quadrimestre de 2015. Disponível em: www.univali.br/direitoepolitica - ISSN 1980-7791.

"consideração às condições fáticas e jurídicas". Entretanto, diz que a ponderação "produz inevitavelmente discricionariedade". Entendem que no Brasil "a ponderação está associada à 'proporcionalidade', entendida como um 'princípio' (sic)".

Lenio Streck, prossegue, dizendo que a discricionariedade e o ativismo judicial devem ser combatidos e o compromisso do jurista deve ser com a Constituição e com a lei, "[...]no interior da qual há uma discussão, no plano da esfera pública, das questões ético-morais da sociedade". ${ }^{35}$

Conclui o autor antes referido, que para se preservar a autonomia do Direito o juiz deve evitar os "predadores" externos ${ }^{36}$, ou seja, a decisão não pode ser fundamentada exprimindo critério de Economia, de Moral ou de Política, o critério tem que ser sempre jurídico, pois caso contrário estaria diante do ativismo judicial.

O ativismo está presente no STF. O caso mais emblemático, exemplo clássico de ativismo judicial, é da ADPF 178, na qual a Procuradoria-Geral da República busca regulamentar a união entre pessoas do mesmo sexo e garantir-lhes os mesmos direitos dos companheiros heterossexuais pela via judicial, alterando o artigo 1.723 do Código $\mathrm{Civil}^{37}$ e o artigo 226, § 30, da Constituição Federal. ${ }^{38}$

O texto constitucional é claro ao referir: homem e mulher e é da competência do Legislativo, observando as formas legais, a alteração do texto.

35 STRECK, Lenio Luiz. O que é isto - decido conforme minha consciência? 3. Ed. Porto Alegre: Livraria dos Advogados, 2012. p. 110

36 STRECK, Lenio Luiz. Verdade e Consenso: constituição, hermenêutica e teorias discursivas. 4. Ed. São Paulo: Saraiva, 2011. p. 44.

37 Art. 1.723. É reconhecida como entidade familiar a união estável entre o homem e a mulher, configurada na convivência pública, contínua e duradoura e estabelecida com o objetivo de constituição de família.

38 Art. 226. A família, base da sociedade, tem especial proteção do Estado. § 30 - Para efeito da proteção do Estado, é reconhecida a união estável entre o homem e a mulher como entidade familiar, devendo a lei facilitar sua conversão em casamento. 
DONEL, Pedro Roberto; CATTANI, Marcos José Campos. Futebol ou educação: escolha do Estado ou do Judiciário. Revista Eletrônica Direito e Política, Programa de Pós-Graduação Stricto Sensu em Ciência Jurídica da UNIVALI, Itajaí, v.10, n.2, 10 quadrimestre de 2015. Disponível em: www.univali.br/direitoepolitica - ISSN 1980-7791.

Evidente que os direitos homossexuais precisam ser regulamentados, mas isto deve ser feito obedecendo a representação social, obedecendo a sociedade democrática em que vivemos.

\section{JUDICIALIZAÇÃo dA POLÍtICA. A DECISÃo DO JUIZ ALEXANDRE MORAIS DA ROSA, A POSIÇÃO DO TRIBUNAL DE JUSTIÇA DE SANTA CATARINA E DO STJ}

A decisão liminar nos autos do processo no 038.03.008229-0, da Vara da Infância e Juventude da Comarca de Joinville foi cassada no Agravo de Instrumento no 2003.010276-0, em $1^{\circ}$ de junho de 2004.

Naquele momento o Judiciário não estava pronto para a judicialização da política, mas a jurisprudência evoluiu e hoje a questão é vista com naturalidade nos tribunais brasileiros.

Mas é importante destacar que a decisão do juiz Alexandre Morais da Rosa chamou atenção para a questão do ativismo e judicialização da política quando poucos se aventuravam a falar sobre o tema, principalmente no âmbito do Judiciário. Nas notas de rodapé da sentença o magistrado traz uma intensa bibliografia, com destaque para Luigi Ferrajoli, e sua obra Direchos y Garantias.

Cabe destacar que tratava-se de uma ação civil pública apresentada pelo representante do Ministério Público contra o Município de Joinville, em que se alegou que este destinou $R \$ 1.750 .000,00$ (um milhão e setecentos e cinqüenta mil reais) para desapropriação de área destinada à construção de estádio de futebol e requereu a concessão de liminar para que a Secretaria Municipal de Educação e Cultura abrisse imediatamente matrícula para todas as 2.948 crianças em lista de espera em educação infantil, e a inclusão no orçamento das verbas necessárias à garantia das vagas pleiteadas.

O juiz não teve dúvidas, deferiu a liminar, posteriormente cassada pelo Tribunal de Justiça. O Estádio foi construído e o JEC está na primeira divisão como já dito. 
DONEL, Pedro Roberto; CATTANI, Marcos José Campos. Futebol ou educação: escolha do Estado ou do Judiciário. Revista Eletrônica Direito e Política, Programa de Pós-Graduação Stricto Sensu em Ciência Jurídica da UNIVALI, Itajaí, v.10, n.2, 10 quadrimestre de 2015. Disponível em: www.univali.br/direitoepolitica - ISSN 1980-7791.

Mas importante trazer para o presente artigo as citações doutrinárias feitas pelo magistrado para fundamentar sua decisão, principalmente o Garantismo Jurídico de Luigi Ferrajoli, que não permite, por nenhum dos três poderes, a violação dos direitos fundamentais.

Salienta-se que o crédito da pesquisa a partir deste momento é do juiz Alexandre Morais da Rosa que destrinchou a "racionalidade da proposta" de Ferrajoli, a fim de fundamentar a liminar ${ }^{39}$.

Luigi Ferrajoli, segundo o Juiz, indica frentes garantistas ${ }^{40}$, diferenciando a validade e forma da vigência formal, que a democracia tem uma dimensão substancial e não apenas formal e que o juiz sujeita-se a lei somente quando ela for formal e materialmente adequada, ou seja, de acordo com a dignidade da pessoa humana e seus direitos fundamentais previstos na constituição, com vista a legitimar o Estado Democrático de Direito.

O garantismo pretende garantir os direitos individuais positivados na Constituição ao mesmo tempo em que limita o poder do Executivo e Legislativo ao seu conteúdo substancial/material, independentemente da vontade da maioria. Desta forma, os direitos da minoria também são garantidos.

$\mathrm{Na}$ sequência diz que os direitos fundamentais são indecidíveis, funcionando como verdadeiro marco divisório, impeditivo do avanço do Legislativo. Os atos do Poder Legislativo e do Executivo podem e devem ser controlados através do juízo de validade, em face do ordenamento constitucional, os quais representam os alicerces da existência do Estado Democrático de Direito.

Diz o magistrado, na liminar, que a possibilidade de transformação social pelo Direito, em simetria com o pacto social avivado pela Constituição Federal de 1988 representa a mais relevante atuação social do Poder Judiciário de índole

39 As idéias foram aprofundadas no livro: ROSA, Alexandre Morais da. Garantismo Jurídico e Controle de Constitucionalidade Material. Florianópolis : Habitus, 2002 e O que é garantismo. Florianópolis : Habitus, 2003.

${ }^{40}$ FERRAJOLI, Luigi. Derechos y garantías - La ley del más débil. Madrid : Trotta, 1999, p. 20. 
DONEL, Pedro Roberto; CATTANI, Marcos José Campos. Futebol ou educação: escolha do Estado ou do Judiciário. Revista Eletrônica Direito e Política, Programa de Pós-Graduação Stricto Sensu em Ciência Jurídica da UNIVALI, Itajaí, v.10, n.2, $1^{0}$ quadrimestre de 2015. Disponível em: www.univali.br/direitoepolitica - ISSN 1980-7791.

substancialista. O juiz tem uma função democrática de fazer acontecer da Constituição por todos os Poderes, até do Judiciário.

O juiz como garantidor da Constituição, não pode permitir violações aos fundamentos constitucionais, e ficar indiferente e passivo diante de legislações infraconstitucionais que avancem sobre as conquistas.

Nesse sentido, compete especificamente ao magistrado, no modelo garantista, renunciar à função de boca repetidora da lei, fazendo a devida oxigenação constitucional.

Luigi Ferrajoli anota:

a sujeição do juiz à lei já não é de fato, como no velho paradigma juspositivista, sujeição à letra da lei, qualquer que seja o seu significado, mas sim sujeição à lei somente enquanto válida, ou seja coerente com a Constituição. E a validade já não é, no modelo constitucionalista-garantista, um dogma ligado à existência formal da lei, mas uma sua qualidade contingente ligada à coerência - mais ou menos opinável e sempre submetida

à valoração do juiz - dos seus significados com a Constituição. Daí deriva que a interpretação judicial da lei é também sempre um juízo sobre a própria lei, relativamente à qual o juiz tem o dever e a responsabilidade de escolher somente os significados válidos, ou seja, compatíveis com as normas constitucionais substanciais e com os direitos fundamentais por elas estabelecidos. ${ }^{41}$

Este o papel do juiz para garantir o Estado Democrático de Direito, salvaguardando as diversas garantias no âmbito social e coletivo previstos na Constituição.

Com base principalmente nestes ensinamentos e no disposto nos arts. $5^{\circ}, \S 20$, 205, 208 e 227 da Constituição Federal de 1988, o juiz entendeu que são direitos individuais, exercitáveis na maior extensão possível, inclusive em ação civil pública, exigível pelo representante do Ministério Público, concedendo a liminar.

\footnotetext{
${ }^{41}$ FERRAJOLI, Luigi. "O Direito como sistema de garantias". In: OLIVEIRA JÚNIOR, José Alcebíades (org.). O novo em Direito e Política. Porto Alegre: Livraria do Advogado, 1997, p.90-91.
} 
DONEL, Pedro Roberto; CATTANI, Marcos José Campos. Futebol ou educação: escolha do Estado ou do Judiciário. Revista Eletrônica Direito e Política, Programa de Pós-Graduação Stricto Sensu em Ciência Jurídica da UNIVALI, Itajaí, v.10, n.2, 10 quadrimestre de 2015. Disponível em: www.univali.br/direitoepolitica - ISSN 1980-7791.

Vale o registro do seguinte trecho da sentença:

[...] que a legitimidade estatal deve ser ponderada pelo Poder Judiciário, sendo absolutamente descabido assistir de camarote - impassível - às violações da Constituição, mormente em Direitos Fundamentais. Se vingar essa tese, para que serve o Poder Judiciário? No verdadeiro Estado Democrático de Direito, no qual as promessas individuais e sociais são implementadas (ou pelo menos se tenta), a tarefa pela diminuição da injustiça social e cumprimento das promessas (saúde, educação, moradia, segurança, moralidade, etc..) é de todo o Poder Público, rompendo-se com a (ultrapassada) rígida tripartição de poderes (Montesquieu), assumindo-se o Poder único e as diversas funções estatais, executiva, legislativa e judiciária. Esta é a feição do Estado Garantista (Ferrajoli)(43). Inexistem mais feudos decisórios. A legitimidade estatal exige que os contrapesos sejam absolutamente eficientes no cumprimento das promessas constitucionais. Por isso 0 administrador público não tem mais um "cheque em branco", podendo o Poder Judiciário analisar o cumprimento dos Direitos Fundamentais e as Garantias dos cidadãos.

Predomina, portanto, no Estado Democrático de Direito a teoria materialista que proporciona uma adequada aplicação da Constituição pelo Judiciário, o que caracteriza a judicialização da política, nos exatos termos da decisão do Juiz Alexandre Moraes da Rosa, cujo fundamento principal é o Garantismo Jurídico de Luigi Ferrajoli.

O que pensa o Tribunal de Justiça de Santa Catarina acerca da decisão do juiz de direito antes referida, determinando a realocação de recursos público do futebol para a educação? A decisão do magistrado foi cassada em grau de recurso, como já dito. Entretanto, uma pesquisa no sítio do Tribunal, utilizando-se como critério de busca "ativismo", resultou em decisões que fazem crer que o TJSC, hoje, está adotando aos poucos a tese da judicialização da política.

Há quatro decisões do Tribunal Barriga Verde, da lavra dos eminentes Desembargadores Pedro Manoel Abreu (Agravo de Instrumento no 2008.0548487 e Apelação Cível no 2010.082906-1), Cesar Abreu (Apelação Cível no 2010.061968-0), e Paulo Henrique Moritz Martins da Silva (Apelação Cível no 2012.042105-0) em que fica evidente a adoção da corrente da judicialização da 
DONEL, Pedro Roberto; CATTANI, Marcos José Campos. Futebol ou educação: escolha do Estado ou do Judiciário. Revista Eletrônica Direito e Política, Programa de Pós-Graduação Stricto Sensu em Ciência Jurídica da UNIVALI, Itajaí, v.10, n.2, 10 quadrimestre de 2015. Disponível em: www.univali.br/direitoepolitica - ISSN 1980-7791.

política, pois nelas o Tribunal catarinense deixa claro que cabe ao Judiciário o controle de políticas públicas (todos os quatros acórdãos citados tratam de saneamento básico), sem que isto ofenda o princípio da separação de poderes, considerando que a atual ordem constitucional obriga o administrador "faltoso ou omisso a tornar factível o princípio vinculante da Supremacia da Constituição". ${ }^{42}$ E que não se trata de ativismo judicial frente à Administração e ao Legislativo. E de fato não o é.

Na ementa do Agravo de Instrumento n. 2008.054848-7, ficou registrado que é proibido o controle judicial das políticas públicas quando o pleito é "genérico, inespecífico e abstrato". Mantra que se repete nas demais decisões. O Tribunal de Justiça barriga verde entende, entretanto, que quando o Executivo age mal ou se omite, provocando "prejuízo concreto, a interesses individuais homogêneos, difusos ou coletivos, é possível o controle judicial de tais políticas por meio de ação coletiva". Esclarece que isso não é ativismo judicial frente ao Executivo e Legislativo, porquanto amparado na Constituição. Ao juiz cabe, "na condição de guardião das promessas (na expressão de Garapón), obrigar o Administrador faltoso ou omisso a tornar factível o princípio vinculante da Supremacia da Constituição.".

No voto, que serviu de condução para os outros três julgados citados, há referência de que a Tripartição dos Poderes, "já era versada por Aristóteles, Locke e Rousseau, embora Montesquieu seja efetivamente considerado, pela academia, o seu grande mentor" ${ }^{\prime 4}$.

Na Apelação Cível no 2010.082906-1, também do Desembargador Pedro Manoel Abreu, os mesmos fundamentos são adotados, sendo que a controvérsia reside sobre a ausência de política pública efetiva, voltada ao saneamento básico no Município de Cunhataí, o que sujeita a população a várias doenças, com a degradação do meio ambiente e poluição de águas que servem de abastecimento a própria cidade e de cidades vizinhas. O acórdão faz referência que a falta de saneamento básico importa grave omissão que afeta diretamente três postulados

42 Ementa do Agravo de Instrumento no 2008.054848-7.

${ }^{43}$ Agravo de Instrumento no 2008.054848-7. 
DONEL, Pedro Roberto; CATTANI, Marcos José Campos. Futebol ou educação: escolha do Estado ou do Judiciário. Revista Eletrônica Direito e Política, Programa de Pós-Graduação Stricto Sensu em Ciência Jurídica da UNIVALI, Itajaí, v.10, n.2, $1^{0}$ quadrimestre de 2015. Disponível em: www.univali.br/direitoepolitica - ISSN 1980-7791.

constitucionais: a dignidade da pessoa humana (CF, art. 10, III), o direito à saúde (art. 1967) e ao meio ambiente saudável (art. 225).

Já na Apelação Cível no 2010.061968-0, relatada pelo Desembargado Cesar Abreu, também em pauta a falta de saneamento básico, agora no Município de Dionisio Cerqueira, e os mesmos argumentos foram usados para justificar a intervenção do Judiciário no controle judicial das políticas públicas, considerado pelo Desembargador como direito fundamental de segunda dimensão (ou geração). Diz o Desembargador Cesar Abreu que foi superado o dogma de que a intromissão atenta contra o princípio da separação de poderes, pois a atual ordem constitucional, que confere atribuições e obrigações a todos os poderes, permite por meio do sistema de freios e contrapesos, que um poder fiscalize 0 outro e postule, no plano jurisdicional, mediante grave ponderação do que se convencionou denominar "mínimo existencial" e "reserva do possível", que se imponha ao poder inadimplente o desempenho de deveres e obrigações que the são ditadas diretamente pela própria Carta e pela legislação que a conforma, segundo assinalou o Ministro do STF Gilmar Mendes no Agravo Regimental no 47.44

A Apelação Cível no 2012.042105-0 trata de uma ação de obrigação de fazer proposta contra o Município de Lauro Muller, para: 1) elaborar seu Código Sanitário Ambiental; 2) constituir uma entidade reguladora e fiscalizadora do serviço; 3) estruturar a tarefa de vigilância sanitária; 4) realizar plano de saneamento; e 5) definir a forma de prestação da atividade. A apelação foi provida para julgar procedente a ação, com os mesmos argumentos antes referidos, acrescentando o relator desembargador Paulo Henrique Moritz Martina

\footnotetext{
44 Sobre o "abuso" da ponderação Lenio Streck, em artigo publicado no dia 7 de janeiro de 2014, no famoso sítio Conjur, faz uma dura crítica ao parágrafo 20 do artigo 486 do NCPC ("No caso de colisão entre normas, o juiz deve justificar o objeto e os critérios gerais da ponderação efetuada, enunciando as razões que autorizam a interferência na norma afastada e as premissas fáticas que fundamentam a conclusão"), implorando para que ele seja vetado pela Presidente, pois caso contrário abriria as portas para o ativismo Judicial. No mesmo artigo tmbém faz referência a uma tese de doutorado de Fausto de Moraes, Premio Capes 2014, que mostra "que a nossa Suprema Corte, nas quase duzentas vezes que lançou mão da ponderação nos últimos dez anos, em nenhum dos casos o fez nos moldes propostos por seu criador alemão". O alemão a que se refere é R. Alexy, o criador da ponderação (Abwägung) da Teoria da Argumentação. Acessado no dia 7 de janeiro de 2015: http://www.conjur.com.br/2015-jan-08/senso-incomum-ponderacao-normas-cpccaos-dilma-favor-veta
} 
DONEL, Pedro Roberto; CATTANI, Marcos José Campos. Futebol ou educação: escolha do Estado ou do Judiciário. Revista Eletrônica Direito e Política, Programa de Pós-Graduação Stricto Sensu em Ciência Jurídica da UNIVALI, Itajaí, v.10, n.2, 10 quadrimestre de 2015. Disponível em: www.univali.br/direitoepolitica - ISSN 1980-7791.

da Silva, na própria ementa, uma decisão do STJ, no Recurso Especial no 650.728, do ministro Herman Benjamin, onde diz que no Brasil, ao contrário de outros países, o juiz não cria obrigações de proteção do meio ambiente. Elas estão na lei. "Daí não precisamos de juízes ativistas, pois o ativismo é da lei e do texto constitucional". Arremata "que o judiciário não é assombrado pro um oceano de lacunas ou um festival de meias palavras legislativas. Se lacuna existe, não é por falta de lei, nem mesmo por defeito na lei; é por ausência ou deficiência de implementação administrativa e judicial dos inequívocos deveres ambientais estabelecidos pelo legislador".

Já no Superior Tribunal de Justiça, o termo ativismo aparece no Recurso Especial no 666.419/SC, de relatoria do ministro Luiz Fux, como maior atuação do Poder Judiciário, numa discussão acerca da possibilidade do juiz usar o sistema BACEN JUD para penhorar bens do devedor em execução fiscal.

No Recurso Especial no 540.179/SP, também relatado pelo ministro Luiz Fux, o ativismo é compreendido como maiores poderes instrutórios do magistrado. Nesse caso o relator determinou, de ofício, a realização de uma nova perícia judicial.

Desta forma, fica demonstrado que o Tribunal de Justiça de Santa Catarina tem uma compreensão melhor e separa ativismo de judicialização da política.

No Superior Tribunal de Justiça o termo é empregado como sinônimo de um papel mais atuante do juiz na condução do processo civil, especialmente na instrução probatória, o que não é considerado ativismo judicial.

O Supremo Tribunal Federal, com o exemplo da união homoafetiva, tem sim um ativismo claro, ultrapassando sua competência Constitucional.

\section{CONSIDERAÇÕES FINAIS}

O conceito de ativismo judicial ainda não foi desenvolvido pela doutrina, confundindo-se com protagonismo judicial, que pode ser tanto o ativismo 
DONEL, Pedro Roberto; CATTANI, Marcos José Campos. Futebol ou educação: escolha do Estado ou do Judiciário. Revista Eletrônica Direito e Política, Programa de Pós-Graduação Stricto Sensu em Ciência Jurídica da UNIVALI, Itajaí, v.10, n.2, 10 quadrimestre de 2015. Disponível em: www.univali.br/direitoepolitica - ISSN 1980-7791.

propriamente dito (tomada de decisões por um ato de vontade, por critérios morais, políticos, não jurídicos por parte dos juízes e tribunais) com a judicialização da política (tomada de decisões com base nos direitos fundamentais e sociais previstos na Constituição Federal, dando vida ao Estado Democrático de Direito).

Resta claro que não se pode importar o ativismo judicial para nossas terras, considerando que a nossa Constituição apresenta um vasto conteúdo normativo, diferente da norte-americana. Nosso texto constitucional estabelece os limites formais e materiais da intervenção judicial. A "leitura moral da Constituição" de Dworkin e a "constituição invisível" de Tribe não se aplicam as terras tupiniquins, portanto.

Aqueles que defendem a discricionariedade judicial acabam atentando contra a democracia, considerando a intensa judicialização a que se tem assistindo atualmente no Brasil e no mundo. Ao aplicar a sua vontade o juiz ou tribunal está ignorando o Estado Democrático de Direito.

Por fim, em tempos de Novo Código de Processo Civil importante olhar para o passado, de modo a aprender com o mesmo a se evitar a repetição dos erros. A advertência é necessária quando vemos hoje juristas defendendo o ativismo judicial, com fundamento em algumas teorias da vontade para a defesa de uma flexibilização integral (privatista) do regramento processual, especialmente em decorrência da ampla cláusula de negociação processual trazida na nova lei (art. 190 do CPC de 2015). O processo deve ser pensado no seu papel instrumental, com a função social, política e econômica.

Assim caminha o Constitucionalismo Contemporâneo (neoconstitucionalismo para os espanhóis), na qual se exige a aplicação intransigente da Constituição, sem discricionariedade e arbitrariedade judicial, mas com a admissão da judicialização da política. 
DONEL, Pedro Roberto; CATTANI, Marcos José Campos. Futebol ou educação: escolha do Estado ou do Judiciário. Revista Eletrônica Direito e Política, Programa de Pós-Graduação Stricto Sensu em Ciência Jurídica da UNIVALI, Itajaí, v.10, n.2, $1^{0}$ quadrimestre de 2015. Disponível em: www.univali.br/direitoepolitica - ISSN 1980-7791.

\section{REFERÊNCIAS DAS FONTES CITADAS}

ALEXY, Robert. Constitucionalismo discursivo. Tradução de Luís Afonso Heck.

2. Ed. Porto Alegre: Livraria do Advogado, 2008.

BONAVIDES, Paulo. Do Estado Liberal ao Estado Social. 8. ed. São Paulo: Malheiros Editores, 2004.

CANOTILHO, José Joaquim Gomes. Constituição dirigente e vinculação do legislador: contributo para a compreensão das normas constitucionais programáticas. 2 ed. Coimbra: Coimbra Editora, 2001.

CARBONELL, Miguel (Org.). Teoría del neoconstitucionalismo: ensayos escogidos. Madrid: Trota, 2007.

DWORKIN, Ronald. Freedam's Law: the moral reading of the american constitution. Oxford: Oxford University Press, 2005.

DWORKIN, Ronald. Law as Interpretatition. In; - A matter of principle. New York: Oxford University Press, 2001.

ELY, John Hart. Democracy and Distritus: a Theory of judicial review, $11^{\text {a }}$ edição, Cambridge, Harvard University, 1995.

FERRAJOLI, Luigi. Derechos y garantías - La ley del más débil. Madrid : Trotta, 1999.

FERRAJOLI, Luigi. "O Direito como sistema de garantias". In: OLIVEIRA JÚNIOR, José Alcebíades (org.). O novo em Direito e Política. Porto Alegre: Livraria do Advogado, 1997.

FERRAJOLI, Luigi. Sobre los derechos fundamentales. Tradução de Miguel Carbonell. In:

LAMEGO, José. Hermenêutica e jurisprudência: análise de uma "recepção". Lisboa: Fragmentos, 1990.

LARENZ, Karl. Medologia de La ciência del derecho. Tradução de Marcelino Rodriguez Molinero. Barcelona: Ariel S.A., 1994.

LOPEZ MEDINA, Diego Eduardo. Teoria Impura del direcho: La transformacion de la cultura jurídica latinoamericana. Bogotá: Lagis, 2004.

ROSA, Alexandre Morais da. Garantismo Jurídico e Controle de Constitucionalidade Material. Florianópolis : Habitus, 2002 e O que é garantismo. Florianópolis : Habitus, 2003.

STRECK, Lenio Luiz. Hermenêutica Jurídica e(m) Crise: uma exploração hermenêutica da construção do Direito. 10. Ed. Porto Alegre: Livraria do Advogado 2011. 
DONEL, Pedro Roberto; CATTANI, Marcos José Campos. Futebol ou educação: escolha do Estado ou do Judiciário. Revista Eletrônica Direito e Política, Programa de Pós-Graduação Stricto Sensu em Ciência Jurídica da UNIVALI, Itajaí, v.10, n.2, $1^{0}$ quadrimestre de 2015. Disponível em: www.univali.br/direitoepolitica - ISSN 1980-7791.

STRECK, Lenio Luiz. O que é isto - decido conforme minha consciência? 3. Ed. Porto Alegre: Livraria dos Advogados, 2012.

STRECK, Lenio Luiz, Verdade consenso: constituição, hermenêutica e teorias discursivas. 4. Ed. São Paulo: Saraiva, 2011.

TRACHTMAN, Michael G. The Supreme's greatest hits: the37 Supreme Court Cases that most directly affesct your life. New York/London Sterling, 2009.

TRIBE, Constitutional Choices. Cambridge: Harvard University Press, 1985.

TRIBE, Laurence. The invisible constitution. Oxford University Press, 2008.

WOLFE, Christopher. Judicial activism: bulwark of freedom or precarious security? New York: Rowman \& Littlefield Publisher, Inc., 1997.

VIANA, Luiz Weneck; CARVALHO, Maria Alice Rezende de; CUNHA MELO, Manuel Palácios; BURGOS, Marcelo Baumann. A judicialização da política e das relações sociais no Brasil. Rio de Janeiro: Editora Ravan.

Submetido em: Março/2015

Aprovado em: Abril/2015 